\title{
Primary Metabolite Profiling and Potential Antioxidants Activity from Fagonia cretica (Stem and Roots)
}

\author{
Sayar $^{* 1}$ and Archana Sharma ${ }^{2}$ \\ ${ }^{* 1}$ Department of Botany, University of Rajasthan, Jaipur, India \\ ${ }^{2}$ Department of Botany, RL Saharia Govt. PG College Kaladera, Jaipur, India
}

\begin{abstract}
Many carbonic compounds are found in medicinal plants, which work as a drug for human body. Fagonia cretica (Linn.) is most valuable therapeutic medicinal plant, commonly known as Dhamasa and belong to Zygophyllaceae family. It is used as: piles, urinary disorders, dysentery, stomach ache, typhoid, cancer and as a blood purifier. Fagonia cretica is a small spiny under-shrub, found in North West India, Punjab, Deccan and Afghanistan. The present study deals in Primary Metabolite Profiling and Potential Antioxidant activity from root and stems of experiment plants. In vitro study of Primary Metabolites such as carbohydrates (starch \& total soluble sugar), proteins, phenols and lipids, primary metabolites are a good source of nutrient and energy for cells and Antioxidant activities like: catalase, peroxidase, lipid peroxidase and FRAP by crude extract of various plant parts (root and stems) was investigated of Fagonia cretica. Antioxidants fight as anti cancer agents in human beings.
\end{abstract}

Keywords: Fagonia cretica; Primary metabolites; UV spectroscopy; Antioxidants.

Article Info: Received 09 July 2019; Review Completed 20 Aug 2019; Accepted 25 Aug 2019; Available online 30 Aug 2019

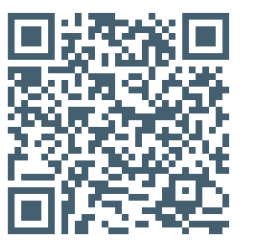

Cite this article as:

Sayar, Sharma A, Primary Metabolite Profiling And Potential Antioxidants Activity From Fagonia Cretica (Stem And Roots), Journal of Drug Delivery and Therapeutics. 2019; 9(4-A):376-380 http://dx.doi.org/10.22270/jddt.v9i4A.3498

*Address for Correspondence:

Sayar, Department of Botany, University of Rajasthan, Jaipur, India

\section{INTRODUCTION:}

In past, plants provided a source of motivation for novel medication complexes, as plant-derived remedies made large influences to human health. Customary medicines are using plant extracts continues to provide health coverage for over $80 \%$ of the world's population, especially in the developing world (Dastagir G et al., (2012); Igbinosa 0. O., et al., (2009). Globalization interferes with infectious disease control at the national level while microbes move freely around the world. Human response to infectious diseases is accustomed by jurisdictional boundaries (Stepanovic S., et al., (2003).

The plants as are used in different system of medicine such as Ayurveda, Allopathy, Unani, Homeopathy and even in other system. About $80 \%$ of the world's population are still dependent on traditional medicines. From ancient times, plants have been a rich source of effective safe medicine and their safe, effective and inexpensive nature; indigenous remedies are popular among the peoples worldwide. Zygophyllaceae family plants are small spiny under-shrub, mostly found in the desert Asia and Africa (Beier BA, et al., (2004). It is reputed to be a medicinal plant in scientific and folkloric literature and its medicinal value are well documented (Chopra RN, et al., (1996); Chopra RM, et al., (1982); Saeed MA, (1969); Hooker JD., (1975). The medicinal properties of the plant were attributed due to its variety of active phytochemical constituents. Fagonia species are reported to be medicinal in the scientific literature as well as in folk medicine (Chopra RM, et al., (1982)). Species of Fagonia have been found to be contains saponins (Khalik A, et al., (2001), alkaloids (Sharawy SM \& Alshammari AM., 2009;), terpenoids (Perroniv A, et al., (2007), sterols (Shoeb HA, et al., (1994), flavonoids (Ibrahim LF, et al., (2012), proteins and amino acids (Sharrma S, et al., (2010), coumarins (Zhan W, et al., (2008) and elements (Fatima K, et al., 1999).

Fagonia cretica is used as: piles, urinary disorders, dysentery, stomach ache, typhoid, cancer and as a blood purifier (Akhtar N. \& Begum S., (2009); Marwat S. K., et al., (2008) to release constipation and as a laxative (Wazir S. M., et al., (2007). It is well known in scientific littérateur to be a therapeutic plant. It is used as diuretic, analgesic, antipyretic, antihepatotoxic, antidysentric, antidote, antiseptic, tonic, bitter, antiasthmatic, stimulant, stomachic and antitumor (Sajid B., et al., (2011). It is a small spiny under-shrub, found in North west India, Punjab, Deccan and Afghanistan (Chopra et al., 1958; Chopra et al.,'1956; 
Hooker, 1875). The plant is highly valued in traditional medicine as a febrifuge, antiasthmatic and useful in skin diseases (Kirtikar and Basu, 1975; Nadkarni, 1954).

Antioxidants are essential for energy supply, detoxification, chemical signalling and immune function (Gulcin I., (2005). These free radicals are usually produced through aerobic respiration. Antioxidants provide protection for living organisms from damage caused by uncontrolled production of reactive oxygen species (ROS) and the concomitant lipid peroxidation, protein damage and DNA strand breaking (Ghoshal S, et al., (1996).
The presence of Antioxidants activities shows the ability of antioxidants to reduce oxidative stress by scavenging of reactive species by hydrogen donation (Erkan $\mathrm{N}$, et al., (2008). Last few year studies have confirmed that free radicals would damage nearby structures including DNA, proteins or lipids. Radical scavenging antioxidants are mainly significant in protecting cells from the injury of free radical (Youwei Z, et al., (1856).

\section{Taxonomical Description:}

Taxonomical description of Fagonia cretica shown in (Fig. No. 1)

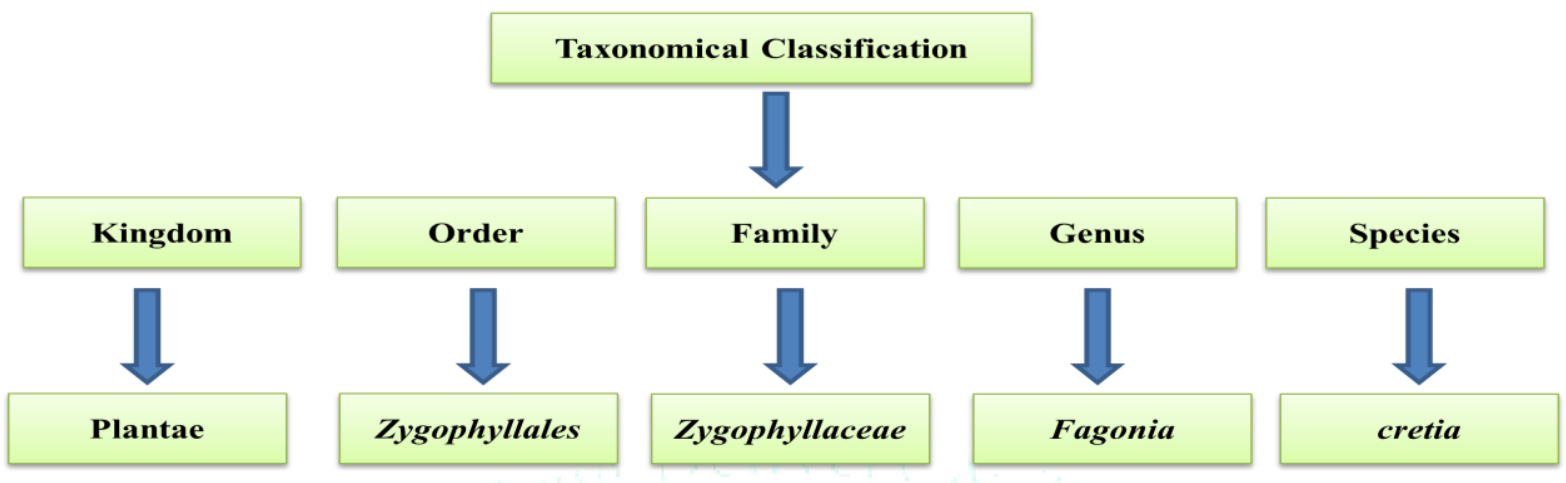

Figure 1

\section{Botanical Description:}

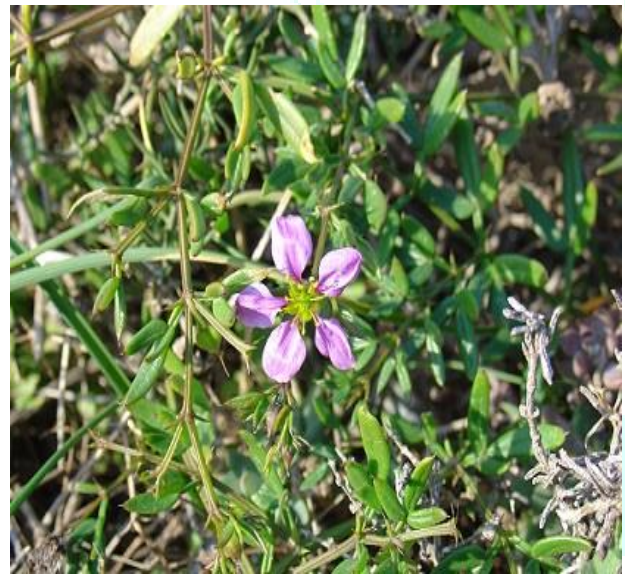

Figure 2: Fagonia cretica (Linn.) plant

Fagonia cretica has tap root system and the roots are cylindrical, tough woody with longitudinal striations. Plant is about $30 \mathrm{~cm}$ tall and the stem is woody, solid, procumbent and branched. Branches are glandular, glabrous and spiny and divided into nodes and internodes. Leaves are cauline, opposite, compound, imparipinnate and trifoliolate rarely top leaves unifoliolate. The central leaflet is glabrous, glandular and linear to narrowly elliptic. The lateral leaflets are smaller than central leaflet and linear to narrowly elliptic. Petiole if present, is $2-16 \mathrm{~mm}$ long, stipulate and the stipules are modified into sharp, slender thorns, which are shorter or rarely longer than the petiole but always shorter than the leaf and polysepalous, polypetalous, solitary and flowers are pedicillate. Petals are purplish pink, and each carpel has two erect collateral ovules, rudimentary disk of nectar glands at the base of the ovary is present, but it is uncertain if the nectar is produced and the plant has capsule-like fruits (Beier 2005).

\section{Geographical Distribution:}

Fagonia cretica (Linn.) is distributed in tropical, subtropical and warm temperate areas of the world, most often presented in dry areas. Algeria, Egypt, Morocco, Tunisia, Cyprus, Saudi Arabia and dry calcareous rocks throughout western India and Pakistan are famous for collection of this plant (Ali et al. 2008).

\section{Synonyms of Fagonia cretica:}

Fagonia cretica (Linn.) synonyms are; Fagonia indica var. schweinfurthii Hadidi; Fagonia Arabica Linn. (Daniel, (2006).

\section{Common Name of Fagonia cretica:}

Bengali - Duralabha; Hindi - Dhamasa, Damahan, Dhamaasa, Hinguaa, Dhanhare; Marathi - Dhamaasaa; Punjabi - Dama, Dhamah, Dhamaha; Sraiki - Dhaman; Tamil - Tulganari; Urdu - Sachchibuti; Tibbi name - Dhamasa; Sanskrit Dusparsha; Unani - Dhamaasaa; Gujarati - Dhamaso and English - Khorason thorn (Rastogi and Mehrotra, 1990; Khare, 2007).

\section{MATERIAL AND METHODS:}

\section{Materials}

\section{Sample collection:}

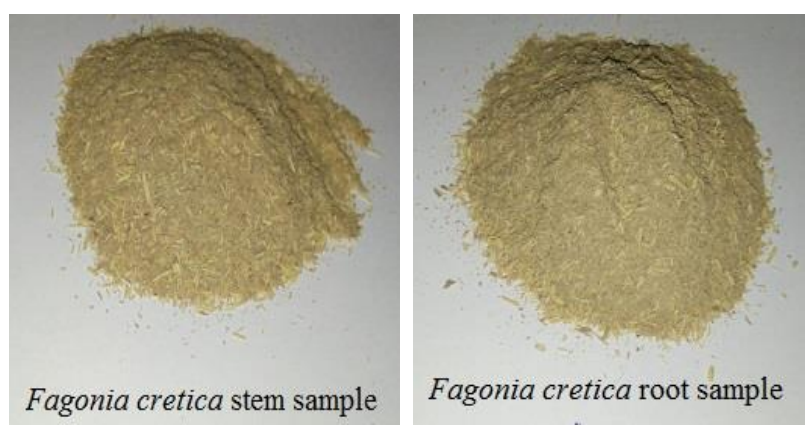

Figure 3 \& 4 
Selective experimental medicinal plants are searched in desert area of Jodhpur and Bikaner, sample were collected of Fagonia cretica (root and stems) and experimental plants samples were deposited in the herbarium of Department of Botany, University of Rajasthan, collect sample and washed with distilled water and shade dried make it powdered for further experiment. Plant samples picture shown in (Fig. No. $3 \& 4)$.

\section{Methods:}

\section{Primary metabolites}

Primary metabolites directly involved in growth and development while secondary metabolites are not involved directly and they have been worked as biocatalysts. Primary metabolites are of prime importance and essentially required for growth and development of plants. Many primary metabolites lie in their impact as precursors or pharmacologically active metabolites of pharmaceutical compounds such as Antipsychotic drugs etc.

\section{PRIMARY METABOLITES: -}

Primary metabolites are like: Carbohydrates (total soluble sugar and starch), proteins, phenols and lipids

\section{CARBOHYDRATE ESTIMATION}

TOTAL SOLUBLE SUGAR: - 80\% ethanol use for extraction according protocol was followed using the method of Mc Cready et al, (1950). $0.1 \mathrm{ml}$ of sample was mixed with $5 \mathrm{ml}$ of $80 \%$ ethanol reagent. Centrifuge at $10000 \mathrm{rpm}$ for $20 \mathrm{~min}$ then supernatant collects in test tube. Add $5 \mathrm{ml} \mathrm{H}_{2} \mathrm{SO}_{4}$ with $1 \mathrm{ml} 5 \%$ phenol then mix by vortex. Now kept sample at room temperature for 20 minutes. Absorbance was read at (wavlength) $490 \mathrm{~nm}$ against a reagent blank. The analysis was performed in triplicates and the results were expressed as $\mathrm{mg}$ /gram dry weight sample.

STARCH: - The protocol was followed using the method of Loomis and Shull (1973) for total soluble sugar. Take $5 \mathrm{ml}$ of $80 \%$ ethanol in a test and mix with $0.1 \mathrm{ml}$ plant sample, mix properly with the help of vertex and centrifuge at 10000 rpm for 20 minutes, collect pellet and mix with $1 \mathrm{ml}$ perchloric acid $\left(\mathrm{HClO}_{4}\right)$ mix by vertex. Take $1 \mathrm{ml}$ sample in test tube add $5 \mathrm{ml} \mathrm{H}_{2} \mathrm{SO}_{4}$ and $1 \mathrm{ml} 5 \%$ phenol mixing by vortex keep $20 \mathrm{~min}$ room temp. The absorbance was read at $490 \mathrm{~nm}$ against a reagent blank. The analysis was performed in triplicates and the results were expressed as $\mathrm{mg} / \mathrm{g}$ dry weight.

\section{PROTEIN ESTIMATION: -}

$10 \%$ TCA use for protein extraction according here methodology of (Osborne, 1962) was followed. Take $0.1 \mathrm{ml}$ of sample mixed it with $3 \mathrm{ml} 10 \%$ TCA, centrifuge at 15000 rpm for 10 minutes, now take pellet add $10 \mathrm{ml} 5 \%$ TCA mix it by vortex. Now take in a test tube and incubate at $80{ }^{\circ} \mathrm{C}$ for 30 minutes, after incubation cool it and take $1 \mathrm{ml}$ sample from it and add $5 \mathrm{ml}$ alkaline solution with $1 \mathrm{ml}$ Folin \& Ciocalteu's reagent and incubated again for 10 minutes at 37 ${ }^{\circ} \mathrm{C}$ or room temperature. Absorbance was read at $750 \mathrm{~nm}$ (wavlength) against 10\% TCA reagent blank. The analysis was performed in triplicates and the results were expressed $\mathrm{mg} / \mathrm{g}$ dry weight sample.

\section{LIPID ESTIMATION: -}

Distilled water is used for lipid extraction according extraction methodology of Jay ram, (1981) will be followed. Take $0.3 \mathrm{gm}$ sample with $10 \mathrm{ml}$ distilled water and crush it with the help of mortar and pestle. Add $20 \mathrm{ml}$ chloroform $\left(\mathrm{CHCl}_{3}\right)$ with $10 \mathrm{ml}$ methanol $\left(\mathrm{CH}_{3} \mathrm{OH}\right)$ for 20 min kept on room temperature will filter it after $20 \mathrm{~min}$. Now add $20 \mathrm{ml}$
$\mathrm{CHCl}_{3}$ with $2 \mathrm{ml}$ distilled water then proper mixing. Take in separating flask and collect lower layer. Dry it here blank weight less in dry weight take result. The analysis was performed in triplicates and the results were expressed $\mathrm{mg} / \mathrm{g}$ dry weight sample.

\section{PHENOL ESTIMATION: -}

$80 \%$ ethanol is used for extraction total phenol content in each sample was estimated by spectrophotometer method of Bray and Thorpe (1954). Take 0.2 gm sample with $4 \mathrm{ml} \mathrm{80 \%}$ ethanol crush it with the help of mortar and pestle. Centrifuge at $10000 \mathrm{rpm}$ for 10 minutes and collect supernatant and take $1 \mathrm{ml}$ of sample added $1 \mathrm{ml}$ of Folin \& Ciocalteau reagent and incubated at room temperature for 3 minutes. After three minutes $2 \mathrm{ml}$ of $20 \%$ sodium carbonate (Na2CO3) was added, mixed well and incubated the tubes in boiling water bath for 1 minute. Cooled rapidly and read absorbance at $750 \mathrm{~nm}$ (wavlength) against reagent blank. The analysis was performed in triplicates and the results were expressed as $\mathrm{mg} / \mathrm{g}$ sample.

\section{ANTIOXIDANT ACTIVITY}

In future this plant extract are significant sources of natural antioxidant, which may be helpful in preventing the progress of various oxidative stresses and as a possible food supplement or in pharmaceutical industry

FRAP (Ferric reducing antioxidant power)

The FRAP assay was used to estimate the reducing capacity of plant extracts, according to the method of Benzie and Strain (1996). The FRAP reagent contained $2.5 \mathrm{~mL}$ of a 10 $\mathrm{mM}$ TPTZ solution in $40 \mathrm{mM} \mathrm{HCl}, 2.5 \mathrm{~mL}$ of $20 \mathrm{mM}$ $\mathrm{FeCl} 3.6 \mathrm{H} 2 \mathrm{O}$ and $25 \mathrm{~mL}$ of $300 \mathrm{mM}$ acetate buffer (pH 3.6). It was freshly prepared and warmed at $37^{\circ} \mathrm{C}$. $900 \mu \mathrm{l}$ FRAP reagent was mixed with $90 \mu \mathrm{l}$ water and $30 \mu \mathrm{l}$ of the extract. The reaction mixture was incubated at $37^{\circ} \mathrm{C}$ for 30 minutes and the absorbance was measured at $593 \mathrm{~nm}$.

\section{CATALASE}

Catalase activity in our laboratory is measured by a spectrophotometric procedure measuring peroxide removal. It is a direct assay with pseudo-first order kinetics and is measured by the method of Sinha K (1972). The enzyme extract $(0.5 \mathrm{ml})$ was added to the reaction mixture containing $1 \mathrm{ml}$ of $0.01 \mathrm{M}$ phosphate buffer ( $\mathrm{pH} 7.0$ ), $0.5 \mathrm{ml}$ of $0.2 \mathrm{M} \mathrm{H}_{2} \mathrm{O}_{2}, 0.4 \mathrm{ml} \mathrm{H} \mathrm{H}_{2} \mathrm{O}$ and incubated for different time period. The reaction was terminated by the addition of $2 \mathrm{ml}$ of acid reagent (dichromate/acetic acid mixture) which was prepared by mixing $5 \%$ potassium dichromate with glacial acetic acid (1:3 by volume). To the control, the enzyme was added after the addition of acid reagent. All the tubes were heated for 10 minutes and the absorbance was read at 610 $\mathrm{nm}$. Catalase activity was expressed in terms of $\mu$ moles of $\mathrm{H}_{2} \mathrm{O}_{2}$ consumed/min/mg protein.

\section{LPO (Lipid peroxidase)}

Homogenize $0.1 \mathrm{gm}$ of leaf tissue by adding $0.5 \mathrm{ml} 0.1 \%$ $(\mathrm{w} / \mathrm{v})$ TCA. Centrifuge the homogenate for $10 \mathrm{~min}$ (15000rpm, $\left.4.0^{\circ} \mathrm{C}\right)$. Collect supernatant and mix $0.5 \mathrm{ml}$ of supernatant with $1.5 \mathrm{ml} 0.5 \%$ TBA diluted in $20 \%$ TCA. Incubate in water bath at $95^{\circ} \mathrm{C}$ for $25 \mathrm{~min}$. End reaction by incubating on ice. In case the solution is not clear, centrifuge for a further $5 \mathrm{~min}\left(15000 \mathrm{rpm}, 4.0^{\circ} \mathrm{C}\right)$. Measure the absorbance at 532 and $600 \mathrm{~nm}$ (Health \& Packer, (1968). 


\section{RESULT \& DISCUSSION:}

Primary Metabolites screening assay result shown in (Fig No. 5).

\begin{tabular}{|l|l|l|l|}
\hline \multicolumn{4}{|c|}{$\begin{array}{c}\text { Primary } \\
\text { Metabolites extracts from Fagonia cretica root and stem } \\
\text { (mg/gram dry weight) }\end{array}$} \\
\hline \multirow{3}{*}{ Carbohydrates } & Sotal soluble sugar & 2.91 & \multicolumn{1}{|c|}{ Root result } \\
\cline { 2 - 4 } & Starch & 3.43 & 2.31 \\
\hline Proteins & 16.26 & 2.21 \\
\hline Phenols & 14.11 & 11.28 \\
\hline Lipids & 10.0 & 10.21 \\
\hline
\end{tabular}

Graphical presentation of Primary metabolites from selective medicinal plant parts Fagonia cretica (Fig no. 6).

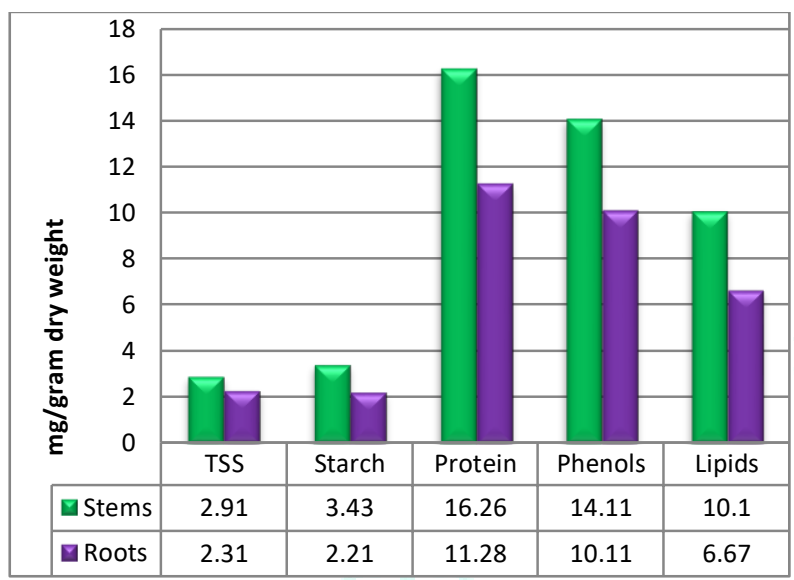

Antioxidant activity from Fagonia cretica stem and roots shown in (Fig No. 7)

\begin{tabular}{|l|c|c|}
\hline $\begin{array}{c}\text { Antioxidant activity from Fagonia cretica stem } \\
\text { and roots } \\
(\mu \mathrm{M} / \mathrm{L} / \mathrm{gram} \text { fresh weight })\end{array}$ \\
\hline & Stems & Roots \\
\hline Catalase & 0.68 & 0.6 \\
\hline Peroxidase & 0.48 & 0.45 \\
\hline Lipid Peroxidase & 11.01 & 4.34 \\
\hline FRAP & 0.37 & 0.31 \\
\hline
\end{tabular}

Graphical presentation of Antioxidant assay stem and roots from Fagonia cretica shown in (Fig no. 8)

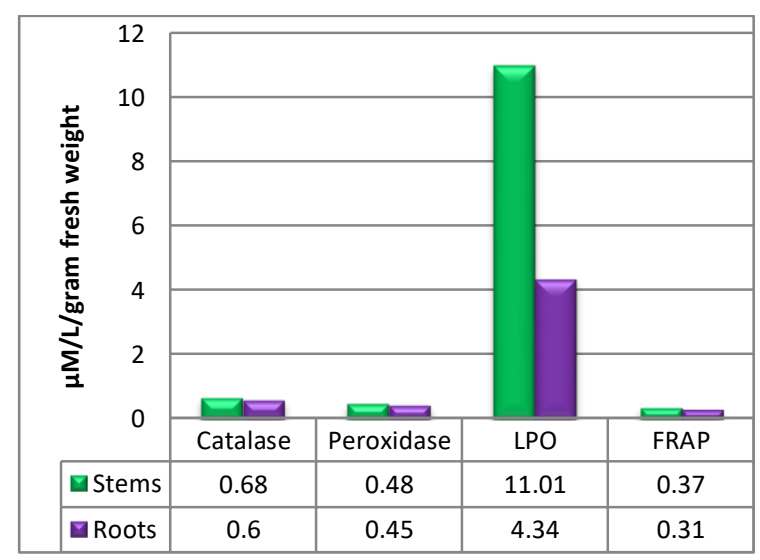




\section{DISCUSSION:}

Finally found great important role of root and stems as potential medicinal activity. Fagonia cretica plant parts are useful for human health, individual and communities. The medicinal values of the selective medicinal plants are lying in some chemical substances that produce a definite physiological action in the human body. Phytochemicals analysed were importance in identifying a new source of therapeutically and industrially valuable compounds having medicinal plants have been chemically investigated. In the present investigation primary metabolites and antioxidants activity are qualitatively and quantitatively analyzed using Fagonia cretica root and stems.

\section{CONCLUSION}

In the present study, quantitative analysis and free radical scavenging activities of root and stems extract of Fagonia cretica were investigated. The extract was found to possess more primary metabolites and it exhibit radical scavenging activities, Based on the results it can be concluded that, the root and stems ethanolic extract of Fagonia cretica which contains high amount of primary metabolites and exhibits free radical scavenging activities. In future this plant extract are significant sources of natural antioxidant, which may be helpful in preventing the progress of various oxidative stresses and as a possible food supplement or in pharmaceutical industry.

\section{REFERENCES:}

1. Akhtar N. and Begum S. "Ethnopharmacological important plants of Jalala, District Mardan, Pakistan”,Pak. J. Plant Sci, 2009; 15, 95.

2. Ali SS, Kasoju N, Luthra A, Singh A, Sharanabasava H, Sahu A and Bora U. Indian medicinal herbs as sources of antioxidants. Food Res Int. 2008; 41(1):1-15. doi:10.1016/j.foodres.2007.10.001.

3. Beier BA, Nylander JAA, Chase MW and Thulin M. Phytogenetic relationship and biogeography of the desert plant genus Fagonia, inferred by parsimony and Bayesian model averaging. M. Mol. Phylogent. Evol. 2004; 33:91-108.

4. Beier BA. A revision of the desert shrub Fagonia (Zygophyllaceae). Syst Biodiver. 2005; 3(3):221-263. doi:10.1017/ S1477200005001684.

5. Chopra RM, Handa KL, Kapur LD and Chopra IC. Indigenous Drugs of India. 2nd ed. New Delhi, India:Academic Press, p. 1982; 507.

6. Chopra RN, Nayar SL and Chopra IC. Glossary of Indian Medicinal Plants. 1st ed. New Delhi:National Institute of Science Communication, 1996; p. 116.

7. Chopra, R.N., Chopra, LC., Handa, K.L. and Kapur, L.D. Chopra's Indigenous Drugs of India, 2nd ed. Academic Publisher, New Delhi, 1958; p. 507.

8. Chopra, R.N., Nayar, S.L. and Chopra, 1.C. Glossary of Indian Medicinal Plants, CSIR, New Delhi, 1956; p. 116.

9. Daniel M. Medicinal plants: chemistry and properties. Enfield, NH: Science Publishers; 2006; p. 120-121.

10. Dastagir G., Hussain F. and Khan AA. "Antibacterial activity of some selected plants of family Zygophyllaceae and Euphorbiaceae",J.Med Plants Res, 2012; 6, 5360.

11. Erkan N, Ayranci G and Ayranci E. Antioxidant activity of rosemary (Rosmarinus officinalis) extract, Black seed (Nigella sativa) essential oil , carnosic acid, rosmarinic acid and sesamol. Food Chem, 2008; 110:76-82.

12. Fatima K, Khaula S, Kalhoro MA, Muhammad Q and Yasmeen B. Trace elements in indigenous medicinal plants (Rhazya stricta, Vinca rosea and Fagonia cretica). Phytochemistry; 1999; 42:182-3.

13. Ghoshal S, Tripathi VK and Chauhan S. Active constituents of Emblica officinalis. Part I, the Chemistry and antioxidative effects of two hydrolysable tannins, emblicanin A and B. Indian J Chem, 1996; 35 (B): 941-948.

14. Gulcin I. The antioxidant and radical scavenging activities of black pepper seeds. Int J Food Sci Nutr, 2005; 56: 491-499.

15. Hooker JD. Flora of British India. Reeva, London, 1975; p. 425.

16. Hooker, J.D. Flora of British India, Vol. 1, Reeva and Co. Ltd., London, 1875; p.425.

17. Ibrahim LF, Kawashty SA, El-Hagrassy AM, Nassar ML and Mabry TJ. A new kaempferol triglycoside from Fagonia taeckholmiana.: cytotoxic activity of its extracts. J. Carb. Res. 2012; 343:155-8.

18. Igbinosa 0. O., Igbinosa 0. and Aiyegoro O. A. "Antimicrobial activity and phytochemical screening of stem bark extracts from Jatropha curcas (Linn)", Afr. J. Pharm Pharmacol, 2009; 3, 58.

19. Khalik A, Miyase SM, Melek T and Ashaal HA. Further saponins from Fagonia cretica. Dipharmazie, 2001; 56:247-250.

20. Khare, C.P. Indian Medicinal Plants, Springer-Verlag Berlin, Heidelberg, New York, 2007; p. 258.

21. Kirtikar, K. R and Basu, B. D. Indian Medicinal Plants, Vol. 1,2nded. Lalit Mohan Basu Prakashan, Allahabad, 1975; pp. 426428.

22. Marwat S. K., Khan M. A., Ahmad M., Zafar M. and F.U. Rehman "Ethnophytomedicines for treatment of various diseases in D. I. Khan District”, Sarhad J. Agric, 2008; 24, 305.

23. Nadkarni, K.M. Indian Materia Medica,3rd ed. Popular Book Depot, Mumbai, 1954; pp. 533-534

24. Perroniv A, Masullo MA, Basarello C, Hamed AI, Belisario MA and Pizza C. Sulfated Triterpene Derivatives from Fagonia arabica. J. Nat. Prod. 2007;70:584-88.

25. Rastogi, R.P. and Mehrotra, N. Compendium of Indian Medicinal Plants, Vol. 5, CDRI, Lucknow,1990; p. 366.

26. Saeed MA. Hamdard Pharmacopoeia of Eastern Medicine. Hamdard Academy, Karachi, Pakistan, 1969; p. 41-43.

27. Sajid B., Alia E., Rizwana K., Uzma S., Alamgeer and Hafiz M. "Phytochemical screeningand antimicrobial activity of Fagonia cretica plant extracts against selected microbes",Journal of Pharmacy Research, 2011; 4,962.

28. Sharawy SM and Alshammari AM. Checklist of poisonous plants and animals in aja mountain, Hilli Region, Saudi Arabia. Australian J. Basic Appl. Sci., 2009; 3:2217-25.

29. Sharrma S, Gupta V and Sharma G. Phytopharmacology of Fagonia Indica (L): A review. J. Nat. Cons. 2010; 1:143-7.

30. Shoeb HA, Sharada MM, Sayed LAR and Wakeel E. Triterpenoid and sterol glycosides from Fagonia arabica L. J. Pharm. Sci., 1994; 13:41- 8.

31. Stepanovic S., Antic N., Dakic I. and Vlahovic M. S. "In vitro antimicrobial activity of propolis and synergism between propolis and antimicrobial drugs",J. Microb. Res, 2003; 158, 353.

32. Wazir S. M., Saima S., Dasti A. A. and Subhan M. "Ethnobotanical importance of salt range species of district Karak, Pakistan", Pak. J. Plant Sci, 2007; 13, 29.

33. Youwei Z, Jinlian Z and Yonghong P. A comparative study on the free radical scavenging activities of some fresh flowers in southern China. LWT Food Sci Technol, 2008; 411:1586-1591.

34. Zhan W, Krohn K, Draeger S and Schulz B. Bioactive isocoumarins isolated from the endophytic fungus Microdochium bolleyi. J. Nat. Prod. 2008; 71:1078-81. 